\title{
Wiarygodność wyniku badania - walidacja zmechanizowanego badania ultradźwiękowego złączy spawanych
}

\section{Reliability of testing result - validation of mechanized ultrasonic inspection of welded joints}

\section{Streszczenie}

W artykule przedstawiono pewne rozwiązania aplikacyjne TOFD przy badaniach zmechanizowanych ultradźwiękową techniką TOFD + PE obwodowych doczołowych złączy spawanych na rurociągach w zakresie średnic DN $300 \div 800 \mathrm{~mm}$ oraz zakresie grubości $6 \div 20 \mathrm{~mm}$.

Jako podstawowe zalety cyfrowego skanowania techniką TOFD oraz echa PE należy wymienić pełne zobrazowanie stanu złącza w przekroju podłużnym wzdłuż głębokości, co stanowi komplementarną informację do wyników badania radiograficznego oraz podwyższoną wiarygodność wyników - wynikającą z mechanizacji skanowania i zastosowania techniki wielu głowic pracujących w różnych modach do potwierdzania wskazań w tych samych obszarach.

Przedstawiono weryfikację nastaw systemu do ciągłej pracy w układzie zmechanizowanym na próbkach odniesienia (zakres i czułość badania). W szczególności zwrócono uwagę na badania walidacyjne wyników uzyskiwanych techniką TOFD + PE w oparciu o wyniki badania radiograficznego lub ultradźwiękowego ręcznego.

\section{Abstract}

The paper presents application of TOFD technique in mechanized ultrasonic inspection of girth welds on pipelines in the range of diameter DN $300 \div 800 \mathrm{~mm}$ and thickness $6 \div 20 \mathrm{~mm}$.

The full image of weld status in cross-section along its depth can be listed as a good points of digital scanning using combined techniques: TOFD and Pulse Echo - PE. It constitutes complementary information to radiographic inspection and increased results reliability - resulting from mechanized scanning and multiprobe technique, which allowed to confirm the same indication by probes, working in different modes.

It is presented verification of ultrasonic system settings on the specific reference blocks (range and sensitivity settings). The validation of TOFD + PE results in respect of results of radiography or manual ultrasonic be especially studied.

\section{Wstęp}

W artykule przedstawiono pewne rozwiązania aplikacyjne TOFD przy badaniach zmechanizowanych ultradźwiękową techniką TOFD + PE obwodowych doczołowych złączy spawanych na rurociągach $w$ zakresie średnic DN 300 $\div 800 \mathrm{~mm}$ oraz grubości $6 \div 20 \mathrm{~mm}$, wykonanych ze stali węglowych lub niskostopowych.

Dr inż Marek Śliwowski - NDTEST, Warszawa,
Od ponad 10 lat jest ona używana w firmie NDTEST i zakres jej stosowania jest systematycznie rozszerzany na badanie złączy spawanych o różnej grubości przez coraz nowsze rozwiązania techniczne i dokumenty normatywne $[1 \div 3]$.

Przy ustalaniu techniki badania oparto się na normach wyrobu - badania złączy spawanych PN-EN ISO 10863:2011 oraz PN-EN ISO 17640:2011), zaś kryteria akceptacji przygotowywane są zgodnie $z$ dokumentacją projektowo-odbiorczą związaną z danym projektem badawczym. 
Przedstawiono weryfikację nastaw systemu do ciągłej pracy w układzie zmechanizowanym na próbkach odniesienia (zakres i czułość badania). W niniejszym referacie w szczególności zwrócono uwagę na badania walidacyjne wyników uzyskiwanych techniką TOFD + PE w oparciu o wyniki badania radiograficznego lub ultradźwiękowego ręcznego. Zwrócono uwagę na zalety wynikających z cyfrowego zapisu wyników przy zmechanizowanym skanowaniu.

\section{Definicje i terminologia}

Walidacja - jest potwierdzeniem, przez zbadanie i przedstawienie obiektywnego dowodu, że zostały spełnione szczególne wymagania dotyczące konkretnie zamierzonego zastosowania.

TOFD (Time of Flight Diffraction) - ultradźwiękowa technika badań nieniszczących polegająca na rejestracji i cyfrowej wizualizacji impulsów ultradźwiękowych ugiętych dyfrakcyjnie na krawędziach wad, w której podstawą do wyznaczania położenia i rozmiarów wad jest dokładny pomiar czasu przejścia impulsów ultradźwiękowych.

PE (Pulse Echo) - ultradźwiękowa technika badań nieniszczących polegająca na rejestracji i wizualizacji impulsów ultradźwiękowych odbitych od wady, w której podstawą do wyznaczania położenia jest pomiar czasu przejścia, a dla rozmiarów wad - amplituda impulsów ultradźwiękowych.

$(T O F D+P E)$ skaner (setup) - ustawienie głowic o odpowiednio dobranych parametrach (częstotliwość, wielkość przetwornika, rodzaj fali, separacja PCS) do grubości badanego złącza.

Zobrazowanie typu A (A-scan) - standardowe zdjęcie impulsów ultradźwiękowych na ekranie defektoskopu, w którym oś pozioma odpowiada odległości od głowicy, zaś oś pionowa amplitudzie rejestrowanych impulsów ultradźwiękowych.

Zobrazowanie typu B (B-scan) - zdjęcie uzyskiwane w wyniku obróbki cyfrowej wyników skanowania ultradźwiękowego typu B, w którym uzyskuje się przekrój wzdłuż grubości badanego materiału, w płaszczyźnie osi wiązki lub w przekroju prostopadłym do niej.

Zobrazowanie typu C (C-scan) - zdjęcie, uzyskiwane w wyniku obróbki cyfrowej B-scanów, w którym uzyskuje się rzut poziomy wskazań wykrytych wiązką ultradźwiękową w badanym materiale

Fala podpowierzchniowa (Lateral Wave) - fala ultradźwiękowa typu podłużnego tworząca się tuż pod powierzchnią badanego materiału po najkrótszej drodze między głowicą nadawczą a odbiorczą.

W technice TOFD impuls fali podpowierzchniowej jako pierwszy dociera do głowicy odbiorczej i stanowi rodzaj impulsu odniesienia, względem którego odmierza się położenie impulsów od wad.
W technice PE wykorzystuje się specjalny impuls fali podpowierzchniowej, tzw. fali pełzającej I rodzaju (primary creeping wave), która dociera do wad znajdujących się na powierzchni lub tuż pod i echo odbite stanowi informację uzupełniającą dla „strefy martwej” w technice TOFD (rys. 1 i 2 ).

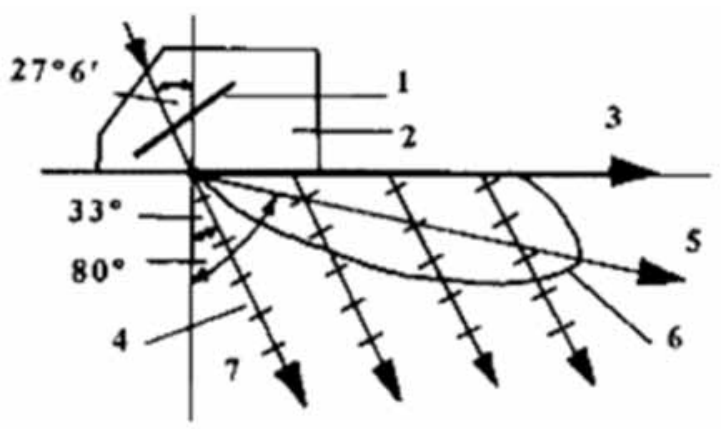

Rys. 1. Zasada tworzenia fal w głowicy fal podpowierzchniowych; 1 - przetwornik, 2 - głowica, 3 - fala pełzająca I rodzaju - fala podłużna, 4 - fala poprzeczna główna, 5 - fali podłużna główna, 6 - obwiednia listka głównego fali podłużnej, 7 - fale poprzeczne wtórne

Fig. 1. The principle of subsurface wave of longitudinal wave probe 1 - transducer, 2 - probe, 3 - primary creeping wave, 4 - head wave - transversal, 5 - head wave - longitudinal, 6 - the envelope of main wave vector, 7 - shear waves - wave mode spreading

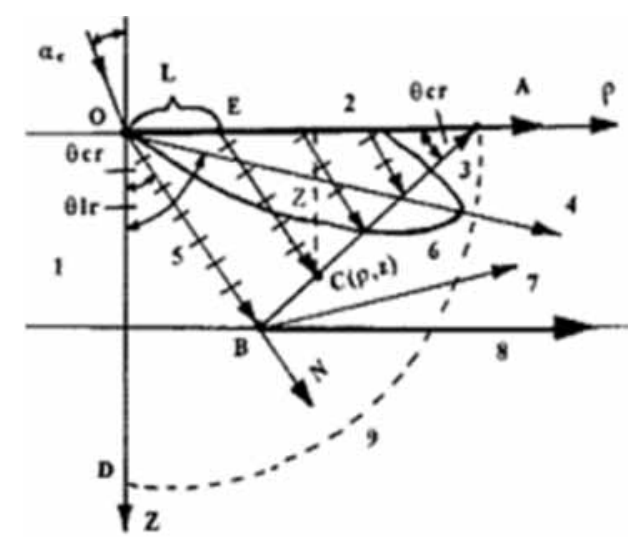

Rys. 2. Konfiguracja wiązek w głowicy fal podpowierzchniowych 1 - obiekt badany, 2 - fala pełzająca I rodzaju, 3 - front fali poprzecznej, 4 - fala podłużna główna I rodzaju, 5 - fala poprzeczna główna, 6 - obwiednia listka głównego fali podłużnej, 7 - fala podłużna główna II rodzaju, 8 - fala pełzająca II rodzaju, 9 - front fali podłużnej

Fig. 2. Beam configurations of creeping wave probe; 1 - object, 2 - primary creeping wave, 3 - wave front of transversal wave, 4 - head longitudinal wave, 5 - head transversal wave, 6 - the envelope of main wave vector, 7 - secondary head longitudinal wave, 8 - secondary creeping wave, 9 - longitudinal wave front

\section{Wyposażenie do badań}

\section{Skaner (TOFD + PE) do badań zmechanizowanych}

Przy badaniu zmechanizowanym złączy techniką TOFD + PE głowice ultradźwiękowe (nadawcza i odbiorcza lub nadawczo-odbiorcza) muszą być prowadzone równolegle do spoiny w ustalonej odległości od siebie oraz środka spoiny. Aby zapewnić równomierne prowadzenie głowic, jak również ich stabilne przyleganie do powierzchni materiału, skonstruowano specjalny zmechanizowany skaner ultradźwiękowy (rys. 3). 
Rama skanera zamontowana jest na wózku napędzanym silnikiem elektrycznym i utrzymywanym na powierzchni rury za pomocą pierścienia prowadzącego z naciętą zębatką.

Głowice ultradźwiękowe montowane są do ramy skanera za pośrednictwem specjalnych wahliwych uchwytów zapewniających dokładne przyleganie głowic do powierzchni rury w czasie ruchu skanera. Konstrukcja ramy umożliwia regulację ustawienia głowic ultradźwiękowych względem siebie oraz względem osi spoiny.

Ważną funkcją skanera jest dostarczanie do jednostki centralnej informacji o położeniu głowic skanujących na obwodzie spoiny. Do odmierzania przesuwu skanera wzdłuż spoiny służy enkoder położenia, którego impulsy generowane są wskutek obrotu koła przylegającego do powierzchni rury.

Do skanera doprowadzony jest specjalnie zabezpieczony kabel zbiorczy, wewnątrz którego znajdują się przewody sygnałowe głowic, kabel enkodera, kabel zasilający silnik oraz przewód doprowadzający wodę. Skaner może poruszać się po obwodzie rury w obu kierunkach z prędkością regulowaną płynnie w zakresie od 0 do $2 \mathrm{~m} / \mathrm{min}$.

Sterowanie ruchem skanera odbywa się za pomocą sterownika umieszczonego w samochodzie i obsługiwanego przez operatora systemu. W przypadkach awaryjnych skaner może zostać zatrzymany za pomocą dodatkowego przycisku STOP znajdującego się bezpośrednio na wózku skanera.

Na rysunku 4 przedstawiono układ głowic ultradźwiękowych zastosowanych w skanerze. Przy badaniach techniką TOFD + PE poszczególne ustawienia głowic

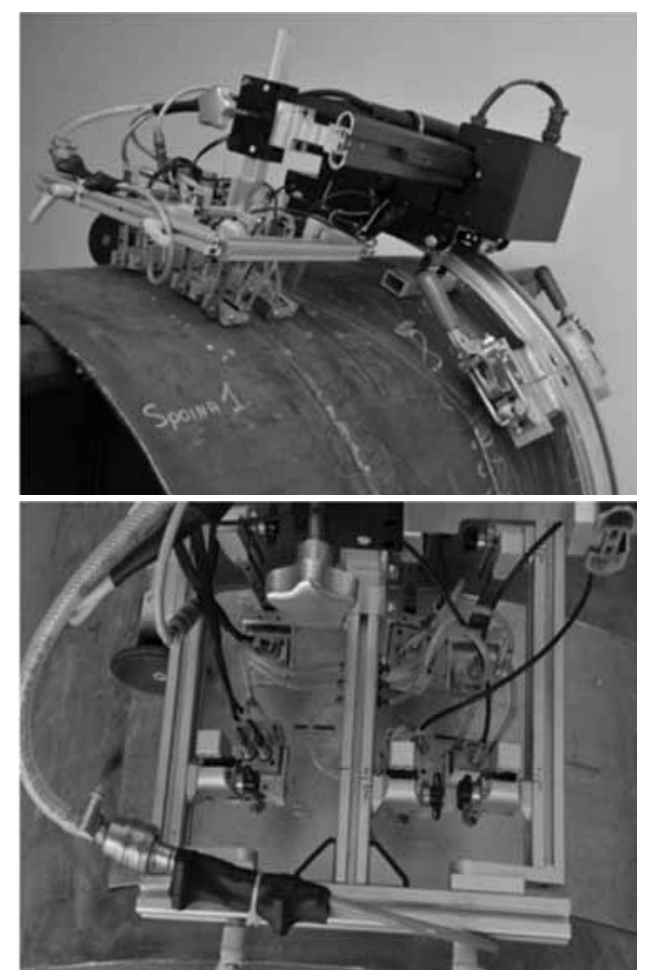

Rys. 3. Zmechanizowany skaner wraz z układem prowadzącym Fig. 3. Mechanical scanner and guiding layout

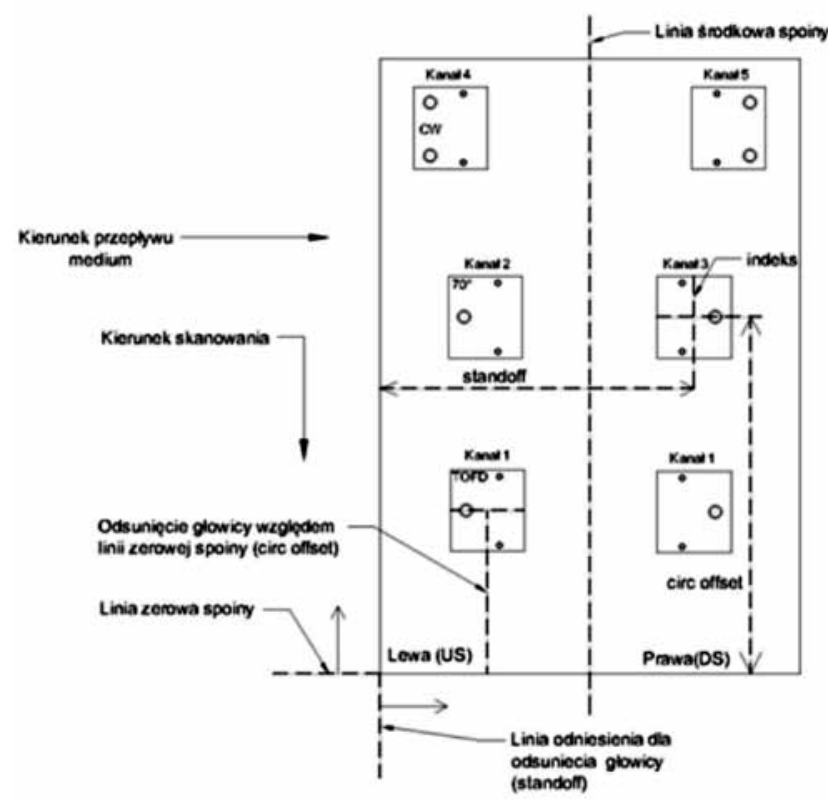

Rys. 4. Układ głowic skanera oraz zasady pozycjonowania głowic Fig. 4. The scanner probe layout and principle of its position

pozycjonowane są na obwodzie rurociągu względem osi spoiny oraz linii zerowej, przyjmowanej zazwyczaj jako pozycja godziny 12 .

\section{Wzorce kalibracyjne i próbki odniesienia}

W badaniu TOFD do oceny wielkości wady wykorzystywana jest informacja o czasie przejścia rejestrowanych impulsów ultradźwiękowych, a nie ich amplituda. Stąd też dokładna kalibracja wzmocnienia badania systemu TOFD nie jest wymagana. Wzmocnienie to powinno być jednak dostatecznie duże, aby zapewnić wykrycie wszystkich impulsów pochodzących od wad, nie powodując przy tym nadmiernego wzrostu poziomu szumów.

W praktyce wzmocnienie dla głowic TOFD ustawiać należy na wartość, przy której poziom szumów strukturalnych, powstających wskutek rozproszenia fal ultradźwiękowych na granicach ziaren materiału, wynosi ok. 5\% pełnej wysokości ekranu. Poziom szumów strukturalnych należy określać po przyłożeniu układu głowic do badanego materiału w miejscu wolnym od wad. Szumy strukturalne ujawniaja się na przebiegu ultradźwiękowym pomiędzy impulsem fali podpowierzchniowej a impulsem echa dna.

Wzmocnienie dla głowic pracujących w technice echa PE należy ustawiać na nacięciach o głębokości odpowiadającej wielkości rejestrowanych wad.

Do weryfikacji nastawy czułości systemu wykorzystywana będzie specjalna próbka odniesienia (rys. 5), w postaci wycinka rury o średnicy DN oraz badanej grubości t, z nacięciami na powierzchni zewnętrznej o głębokościach $0,5 \mathrm{~mm}, 1 \mathrm{~mm}, \mathrm{t} / 4,2 \mathrm{t} / 4$ oraz $3 \mathrm{t} / 4 \mathrm{~mm}$, 
a także z nacięciami na powierzchni wewnętrznej o głębokościach 1, 2 i 3 mm zgodnie z zaleceniami PNEN ISO 10863, zał. A oraz wymaganiami kontraktowymi. Wymiary próbki, wykonanej z badanego materiału rury, wynoszą 400x200xt mm, a nacięcia wykonane są w odstępach uniemożliwiających wzajemne zachodzenie na siebie wskazań.

Dodatkowo do bieżącej kontroli systemu ultradźwiękowego wg PN-EN 12668-3 należy stosować wzorzec Nr 1 wg PN-EN 12223.
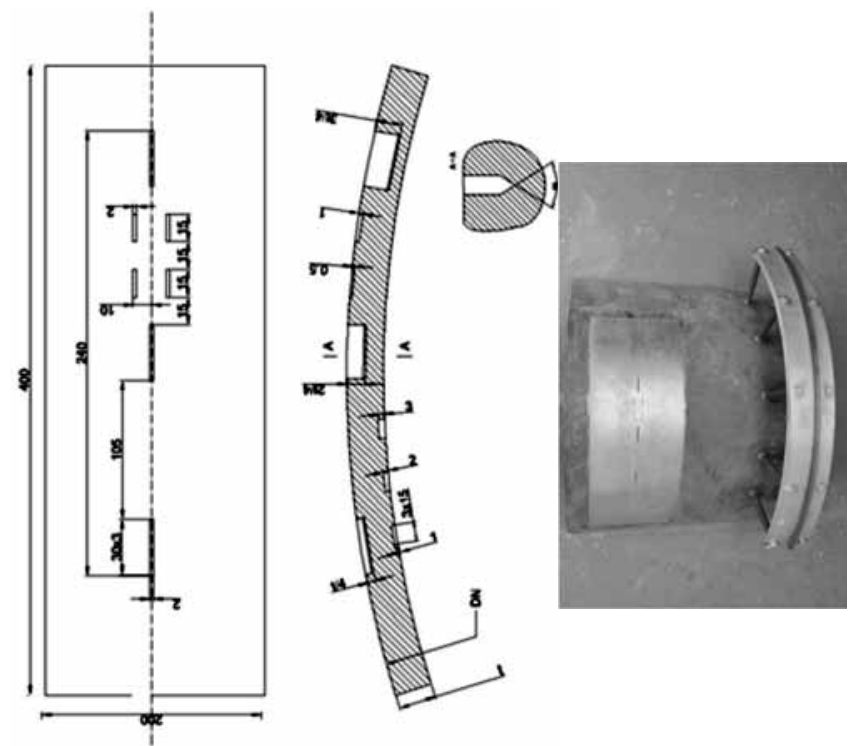

Rys. 5. Próbka odniesienia do ustawiania czułości badania zmechanizowanego systemu ultradźwiękowego TOFD+PE

Fig. 5. The reference block for sensitivity setting of ultrasonic mechanized system TOFD+PE

\section{Wykonanie badania}

\section{Nastawy aparatury}

Nastawianie aparatury powinno być prowadzone w porównywalnych warunkach do tych, z jakimi będzie się miało do czynienia w czasie pomiarów na obiekcie. Przed rozpoczęciem badania TOFD + PE należy określić i ustawić parametry badania odpowiednie dla danej spoiny. Są to w szczególności: typ oraz rozstaw głowic ultradźwiękowych, początek i długość bramki próbkowania oraz wzmocnienie - czułość badania. Ponadto należy sprawdzić i ewentualnie skorygować pozostałe parametry pracy systemu.

Po ustawieniu wszystkich wymaganych parametrów badania należy wykonać skan kontrolnyna próbce odniesienia - dostosowanej do wymiarów i geometrii badanego złącza (rys. 6). Na uzyskanych zobrazowaniach typu B i C powinny być wyraźnie uwidocznione impulsy dyfrakcyjne oraz echa pochodzące od wszystkich nacięć, które znalazły w obszarach przeszukiwania wszystkich głowic skanera TOFD + PE. Jeżeli wskazania te nie występują lub są słabo widoczne (na zobrazowaniu typu A nie osiągają $20 \%$ FSH - pełnej wysokości ekranu), należy sprawdzić i skorygować parametry badania.

\section{Zmechanizowane skanowanie złącza spawanego - zalety techniki wielogłowicowej}

Podstawowym skanowaniem jakie wykonuje się przy badaniu spoin techniką TOFD + PE jest skanowanie typu nierównoległego, w którym głowice ustawione są symetrycznie po obu stronach spoiny i przesuwane równolegle do osi spoiny (rys. 3 i 4). Podczas przesuwu skanera impulsy ultradźwiękowe przechodzące między głowicami (zobrazowania typu A) są systematycznie próbkowane cyfrowo w zakresie ustawionych bramek i zapisywane w pamięci komputera. Przebiegi te są następnie przekształcane w zobrazowania typu B i C, będące obrazem spoiny w przekroju podłużnym lub poprzecznym oraz rzutem na powierzchnię obwodu zewnętrznego badanego złącza (na rysunku 7 podano przykładowy zapis cyfrowy badania objętości złącza skanerem TOFD + PE). Zobrazowanie to umożliwia lokalizację wad na obwodzie spoiny oraz określenie długości, wysokości oraz głębokości zalegania wad.

Na rysunku 7 podano sposób wymiarowania wskazania braku przetopu oraz odróżniania go od wskazań geometrii złącza. Sonogram pokazuje również, jak

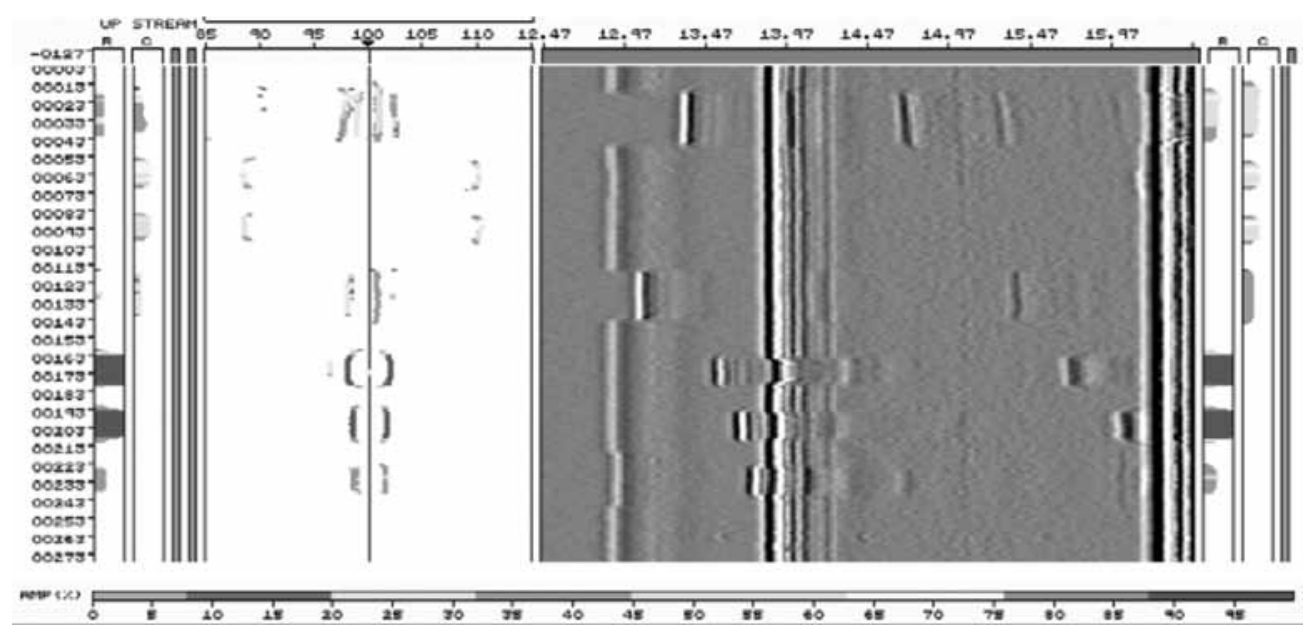

Rys. 6. Skan kontrolny na próbce odniesienia wykonany skanerem TOFD + PE

Fig. 6. The contol scan of reference block done by TOFD + PE scanner 


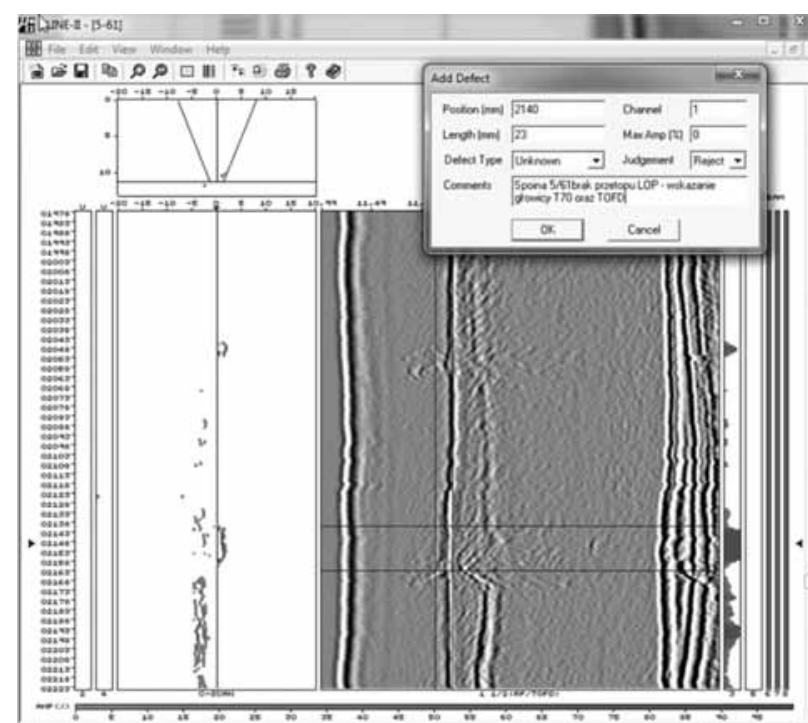

Rys. 7. Przykładowy zapis cyfrowy badania złącza DN $800 \times 11$ wykonany skanerem TOFD + PE - na rysunku pokazano sposób weryfikacji wskazań braku przetopu LOP oraz wskazań geometrii złącza za pomocą głowic fal poprzecznych o kącie wiązki $70^{\circ}$, penetrujących obszar przetopu (kanały 3 i 4 - na poprzecznym B-scanie orientacyjnie zaznaczono przebieg osi wiązki głowicy i szerokość bramki próbkowania) - na podstawie takiej informacji można również zinterpretować wskazanie z głowic TOFD jako pochodzące od braku przetopu

Fig. 7. The exemplary digital scan of DN800x11 mm girth weld done by TOFD + PE scanner - on the diagram verification of lack of penetration (LOP) as well as geometrical indications are presented using additional shear vawe probe of $70^{\circ}$, penetrated root weld area (channels 3 and $4-$ on the upper B-scan scheme of probe beam axis and gate width are shown) - using this additional information one can interprete the TOFD indications of LOP in this area

trudna i niejednoznaczna jest interpretacja braku przetopu tylko na podstawie wskazań dyfrakcyjnych głowicy pracującej w modzie TOFD. Na kolejnych rysunkach podano przykłady analizy, wymiarowania i interpretacji wskazań wykrywanych techniką TOFD + PE, które potwierdzają słuszność stosowania skanowania wielogłowicowego.

\section{Badania walidacyjne techniki TOFD + PE}

Poniżej zamieszczono kilka przykładów działań walidacyjnych, które zawsze powinny towarzyszyć wprowadzaniu nowej techniki badawczej (jaką na rynku polskim jest niewątpliwie cyfrowa technika ultradźwiękowego skanowania z użyciem wielogłowicowych skanerów TOFD+PE) na większych przedsięwzięciach technicznych. Temu celowi służy jednoczesne stosowanie kontroli NDT dwoma metodami objętościowymi. Trzeba mieć przy tym na uwadze znane ograniczenia każdej metody/techniki badawczej i nie oczekiwać pokrywania wyników badania w każdym przypadku.

$\mathrm{Na}$ rysunku 8 przedstawiono pęknięcie podłużnego (101) o długości $I_{x}=192 \mathrm{~mm}$, uzyskane $\mathrm{w}$ ba- daniu radiograficznym (radiogram zdigitalizowany), które zinterpretowano jako wade $w$ przetopie. Obraz UTA - TOFD + PE nie pozostawia wątpliwości co do zgodności lokalizacji i wymiarów pęknięcia, dając dodatkową informację o wysokości i przebiegu wady w przekroju poprzecznym złącza - TOFD-B-scan.

$\mathrm{Na}$ rysunku 9 pokazano badania walidacyjne wskazania przyklejenia wykrytego UTA (LOF: $X+1 \mathrm{x}=$ $1610+452 \mathrm{~mm}$; $\mathrm{h} \sim 1 \mathrm{~mm})$; weryfikacja przez badania radiograficzne (Se-75) ujawniła występowanie słabo kontrastowego wskazania, które bez informacji o wskazaniu UTA można z dużym prawdopodobieństwem pominąć w ocenie. Dokładna ocena radiograficzna przyklejenia pozwala je oszacować jako: $(4012+4013) X+I_{x}$ $=1600+330 \mathrm{~mm}$. Obraz UTA - TOFD + PE nie pozostawia wątpliwości co do lokalizacji i wymiarów, dając dodatkową informację o wysokości i przebiegu wady w przekroju poprzecznym złącza TOFD-B-scan.

Na rysunku 10 pokazano walidacyjne wskazania przyklejenia wykrytego UTA (LOF: $\mathrm{X}+\mathrm{I}_{\mathrm{x}}=39+36 \mathrm{~mm}$; $\mathrm{h} \sim 1,5$ $\mathrm{mm})$; weryfikacja przez badanie radiograficzne (Se-75) ujawniła typowe dla radiografii wskazanie przyklejenia. Dokładna klasyfikacja (4011): $X+I_{x}=45+35 \mathrm{~mm}$. Obraz UTA - TOFD + PE również nie pozostawia wątpliwości co do lokalizacji i wymiarów, natomiast ocena radiograficzna wymaga bardzo uważnego przeglądania.
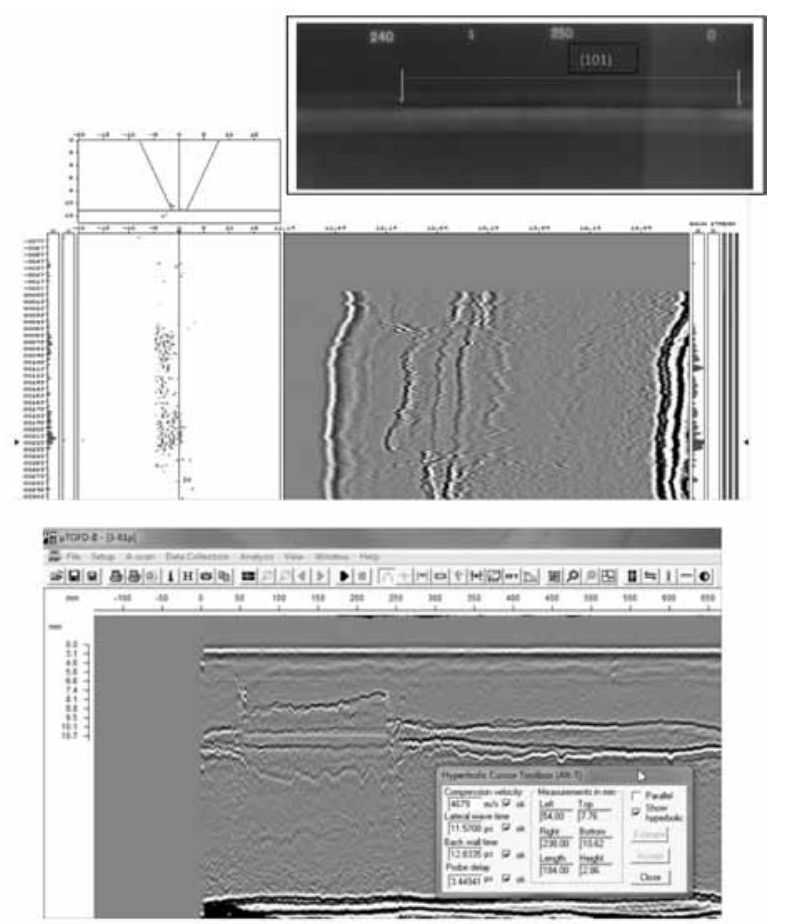

Rys. 8. Badania radiograficzne (Se-75) ujawniły występowanie pęknięcia (101) w inii przetopu o współrzędnych $X+I_{x}=2410+192 \mathrm{~mm}$; badania walidacyjne systemem UTA potwierdziły pęknięcie (Crack $-101: X+I_{x}=54+184 \mathrm{~mm} ; \mathrm{h}=2,86 \mathrm{~mm}$ ). Niezgodność początku wskazania wynika $z$ rozpoczęcia skanowania UTA z przesunięciem ok. $X_{0}=-200 \mathrm{~mm}$ względem „0" radiograficznego

Fig. 8. In radiographic inspection (Se-75) a longitudinal crack (101) occurs along weld root with coordinate $X+I_{x}=2410+192 \mathrm{~mm}$; the UTA scanning confirm an indication - interpreted as a crack -101 : $X+I_{x}=54+184 \mathrm{~mm} ; \mathrm{h}=2,86 \mathrm{~mm}$. The nonconformity of initial coordinates of both indication implies from delay about $X_{0}=-200 \mathrm{~mm}$ in UTA scanning in respect to 


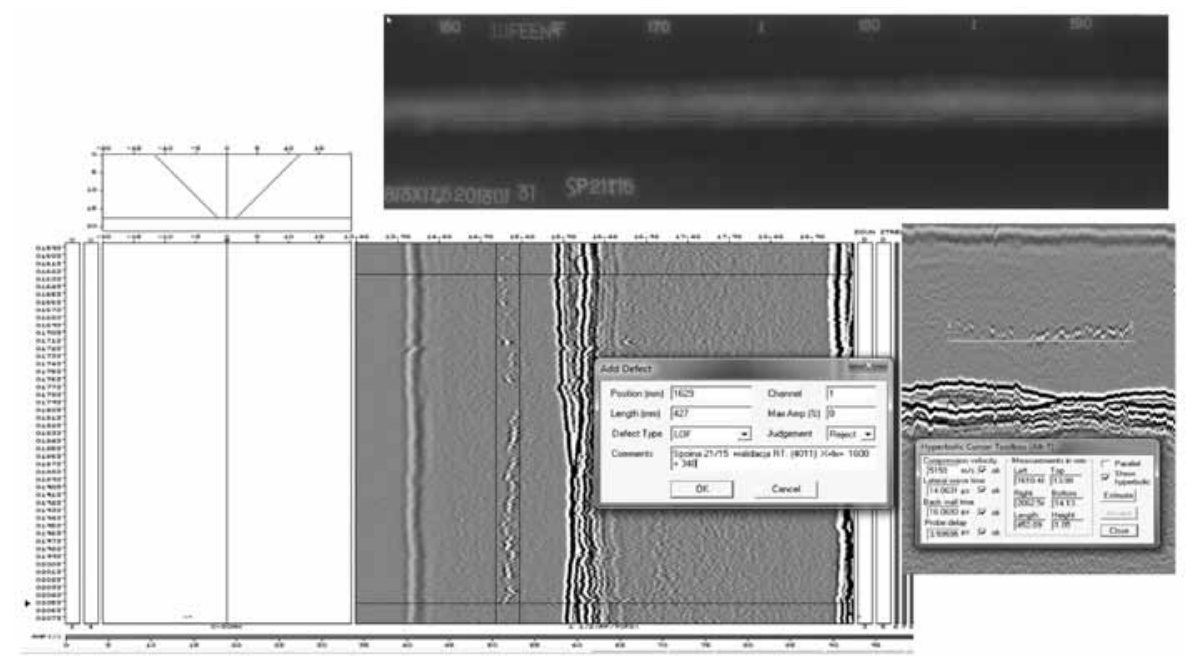

Rys. 9. Badania walidacyjne wskazania przyklejenia wykrytego UTA (LOF: $X+\mathrm{I}_{x}=1610+452 \mathrm{~mm} ; \mathrm{h} \sim 1 \mathrm{~mm}$ ); weryfikacja badania radiograficznego (Se-75) ujawniła przyklejenie przerywane na wskazanym ultradźwiękami odcinku $(4012+4013): X+I_{x}=1600+330 \mathrm{~mm}$; (na radiogramie naniesiono informacyjnie przebieg wskazań przyklejenia obserwowany na oryginalnym rdg analogowym)

Fig. 9. In the UTA scanning a lack of fusion indication (LOF: $X+I_{x}=1610+452 \mathrm{~mm} ; \mathrm{h} \sim 1 \mathrm{~mm}$ )has occurred; the radiographic inspection (Se-75) confirm an indication as an intermittent LOF $(4012+4013): X+I_{x}=1600+330 \mathrm{~mm}$; (on the film is digitally viewed the course of lack of fusion on original analog radiograph).
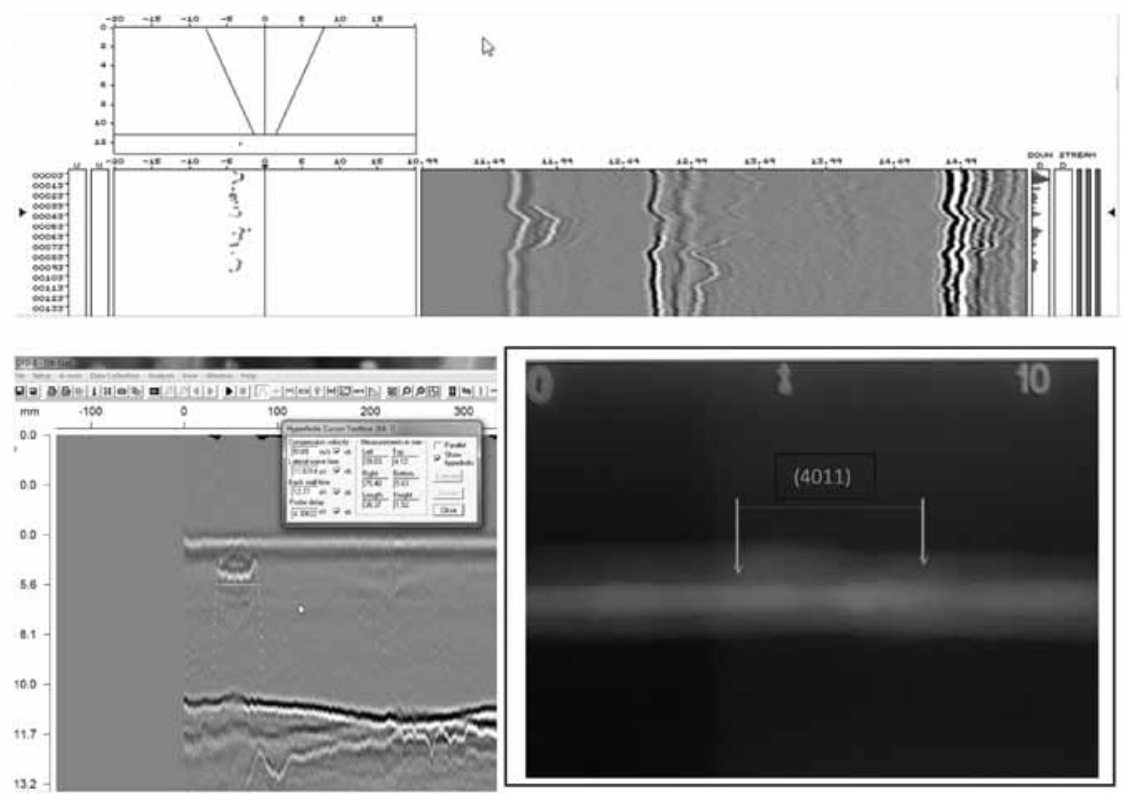

Rys. 10. Badania walidacyjne wskazania przyklejenia wykrytego metodą UTA (LOF: $X+\mid x=39+36 \mathrm{~mm} ; \mathrm{h} \sim 1,5 \mathrm{~mm}$ ); weryfikacja badania radiograficznego (Se-75) ujawniła w przyklejenie na wskazanym przez UTA odcinku(4011): $X+I_{x}=45+35 \mathrm{~mm}$; (na radiogramie naniesiono informacyjnie początek i koniec wskazania)

Rys. 10. In the UTA has occurred $\operatorname{LOF}\left(X+I_{x}=39+36 \mathrm{~mm} ; \mathrm{h} \sim 1,5 \mathrm{~mm}\right)$; Validation by the radiographic inspection (Se-75) confirm an indication (LOF: $X+I_{x}=39+36 \mathrm{~mm} ; \mathrm{h} \sim 1,5 \mathrm{~mm}$ - on the film is viewed the course of LOF on original analog radiograph)

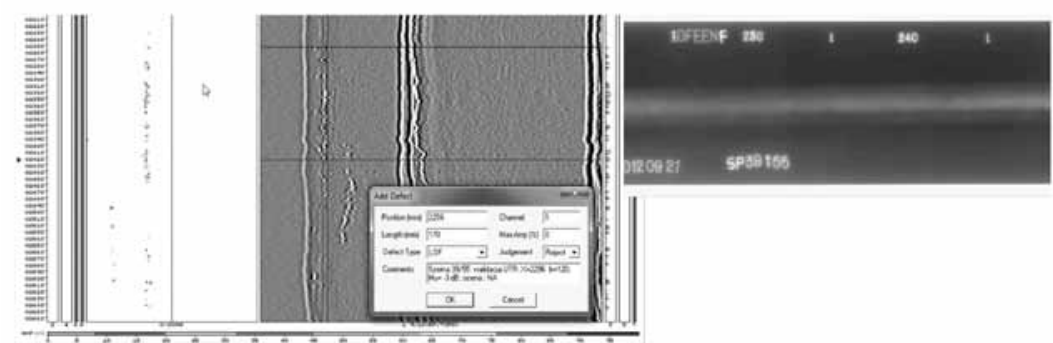

Rys. 11. Badania walidacyjne wskazania przyklejenia wykrytego metodą UTA (LOF: $X+I_{x}=2256+170[\mathrm{~mm}]$; $h=2$ [mm]); weryfikacja ręcznymi ultradźwiękami UTR (LOF: $X+I_{x}=2296+120[\mathrm{~mm}] ; \Delta \mathrm{Hu}=-3 \mathrm{~dB}$ ); Badania radiograficzne $($ Se-75) nie ujawniły występowania przyklejenia na wskazanym przez UTA odcinku

Fig. 11. In the UTA has occurred LOF $\left(X+I_{x}=2256+170[\mathrm{~mm}], h=2\right.$ [mm]); Validation by the manual ultrasonic inspection UTR (LOF: $\left.X+I_{x}=2296+120[\mathrm{~mm}] ; \Delta \mathrm{Hu}=-3 \mathrm{~dB}\right) ;$ The radiographic testing not confirm the indication in the area of interest 
Na rysunku 11 pokazano przykład postępowania walidacyjnego, gdy wskazania przyklejeń wykrytych UTA (LOF1: $X+\mathrm{I}_{\mathrm{x}}=2256+170 \mathrm{~mm} ; \mathrm{h}=2 \mathrm{~mm}$ oraz LOF2: $X+I_{x}=2399+153 \mathrm{~mm} ; \mathrm{h}=5,5 \mathrm{~mm}$ ) w tym samym złączu nie zostają potwierdzone w badaniu radiograficznym (Se-75) .

Wiarygodność wyniku UTA - TOFD+PE została w tym przypadku potwierdzona przez ręczne badania ultradźwiękowe UTR, gdzie w obydwu wskazaniach UTA wykryto przyklejenia na granicy wtopienia przy pomocy standartowych głowic kątowych o kącie $60^{\circ}$ : oraz

$\left(L O F_{U T R 1^{1}}: X+I_{x}=2296+120[\mathrm{~mm}] ; \Delta H_{u}=-3 \mathrm{~dB}\right.$

$\left.L O F_{\text {UTR2 }}: X+I_{x}=2400+140[\mathrm{~mm}] ; \Delta H_{u}=0 \mathrm{~dB}\right)$.

$W$ ramach walidacji wiarygodności wyniku badania pojawił się problem interpretacji wskazań dyfrakcyjnych w badaniach TOFD (por. rys. 12).

Stwierdzono następujące cechy charakterystyczne:

- wskazania te pojawiały się zawsze na zdjęciach głowic TOFD i występowały jako wskazania dyfrakcyjne, charakterystyczne dla rozproszonych wskazań punktowych;

- wskazania występowały z mniejszym lub większym nasileniem i wielkością amplitudy w całym przekroju wzdłuż grubości spoiny;

- miejsce występowania tych wskazań było zawsze związane z sąsiedztwem strefy wpływu ciepła wokół spiralnych spoin hutniczych.

W wyniku przeprowadzonej analizy oraz weryfikacyjnych badań magnetyczno-proszkowych podczas otwierania złącza stwierdzono, że występujące w tych miejscach wskazania dyfrakcyjne (sugerujące występowanie wad o znaczącej, nieakceptowanej długości i wysokości) wynikają ze zmienionej gruboziarnistej struktury złącza hutniczego. Złącza hutnicze wykonywane są metodą spawania pod topnikiem i w ich strefie wpływu ciepła oraz w samym złączu może dochodzić do znacznego rozrostu ziarna, przy wysokich parametrach spawania.

Pokazane przykłady działań walidacyjnych potwierdzają wysoką wiarygodność zastosowanej techniki ultradźwiękowej TOFD + PE, która kumuluje wszystkie zalety związane z cyfrowym zapisem wyników badania wzdłuż długości złącza. Bardzo istotnym elementem wiarygodności wyniku jest mechanizacja procesu skanowania oraz dodatkowe informacje ze stref przypowierzchniowych uzyskiwane za pomocą głowic pracujących w modzie PE, które stanowią o poprawności interpretacji wyników badania.

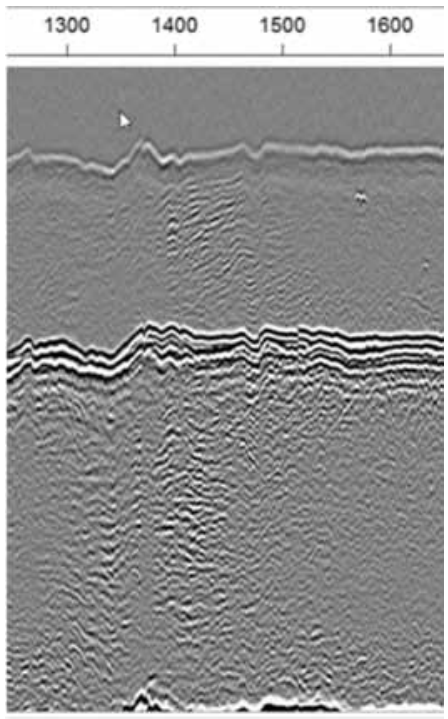

Rys. 12. Obraz wskazań dyfrakcyjnych TOFD na zmienionej gruboziarnistej strukturze złącza hutniczego

Fig. 12. The TOFD image on the coarse grained structure of longitudinal weld and $\mathrm{HAZ}$

\section{Podsumowanie}

Doświadczenia nabyte przez firmę NDTEST podczas stosowania techniki TOFD + PE w zmechanizowanych badaniach złączy spawanych potwierdzają, że stanowi ona istotny krok naprzód w stosunku do klasycznych technik radiograficznych i ultradźwiękowych. Należy jednak podkreślić, że wdrożenie tej techniki do praktyki przemysłowej wymaga pokonania licznych barier technicznych związanych z mechanizacją procesu badania w ciężkich warunkach terenowych.

Uwzględniając wymagania dokumentów normatywnych dla wybranych poziomów techniki badania TOFD oraz doboru zestawów skanera TOFD + PE do grubości badanego złącza, weryfikację nastaw należy opierać na przygotowanych wcześniej próbkach odniesienia, wykonanych z materiału obiektu badanego z zachowaniem wymiarów geometrycznych.
Jako podstawowe zalety cyfrowej i zmechanizowanej techniki skanowania TOFD + PE należy wymienić:

- możliwość badania złączy dla różnych średnic (zakres DN 300 $\div 800 \mathrm{~mm}$ ) o grubościach od 6 do $30 \mathrm{~mm}$, przy stosunkowo niewielkim wzroście nakładu środków i pracochłonności;

- dużą wydajność badania, nieznacznie zależna od

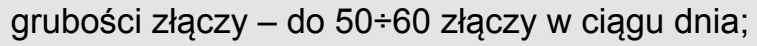

- możliwość wykonywania badań podczas dnia, ze względu na nieszkodliwość ultradźwięków dla otoczenia;

- pełny zapis cyfrowy wyników badania z całej objętości złącza i ocena wyniku badania w czasie rzeczywistym;

- analizę wyników (również zdalnie na odległość) z możliwością dokładnego pomiaru położenia, 
długości oraz głębokości i wysokości wad przy pomocy specjalnego oprogramowania;

- obraz stanu złącza w przekroju wzdłuż głębokości, co stanowi komplementarną informację do wyników badania radiograficznego;

- podwyższoną wiarygodność wyników - wynikającą z mechanizacji skanowania oraz zastosowania techniki wielu głowic pracujących w różnych mo- dach do potwierdzania wskazań w tych samych obszarach.

Technika TOFD + PE z użyciem zmechanizowanych skanerów została efektywnie wdrożona przez NDTEST na obiektach rurociągowych o dużym zróżnicowaniu średnic i grubości, na różnego rodzaju instalacjach w przemyśle gazowniczym i petrochemicznym.

\section{Literatura}

[1] Śliwowski M.: Badanie złączy spawanych cienkich i grubych techniką ultradźwiękową TOFD, Nieniszczące Badania Materiałów, Zakopane 2010

[2] PN-EN ISO 10863:2011: Badania nieniszczące złączy spawanych. Badania ultradźwiękowe - Zastosowanie techniki dyfrakcji fal ultradźwiękowych (TOFD) (oryg.)

[3] PN-EN ISO 17640:2011: Badania nieniszczące złączy spawanych. Badania ultradźwiękowe - techniki, poziomy badania oraz ocena (oryg.).

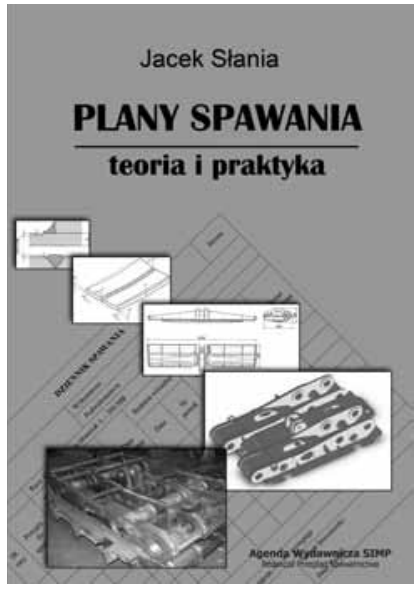

\section{Plany spawania - teoria i praktyka} Jacek Stania

Okładka: twarda

Format: B5

Wydawnictwo: Agenda Wydawnicza SIMP Redakcja Przegląd Spawalnictwa

Strony: 396

Rok wydania: 2013

ISBN 978-83-87982-57-7
Książka podzielona jest na dwie główne części. Pierwsza, obejmująca 10 rozdziałów, stanowi szczegółowe omówienie problemu w ujęciu materiałowym i technologicznym naprężeń własnych, odkształceń powstających w procesie spawania, wpływu parametrów procesu na ich wartość oraz porusza zagadnienie planów spawania w kontekście niezbędnej dokumentacji technologicznej, procesów dodatkowych (np. obróbki cieplnej) oraz wymagań podstawowych norm branżowych. Autor zwraca również uwagę na koszty produkcji spawalniczej, szczególnie istotne na etapie planowania.

Drugą, praktyczną częścią książki są przykładowe plany spawania opracowane i stosowane w praktyce przemysłowej. Zebrane plany zostały opracowane w różny sposób, wskazujący na potrzebę ich usystematyzowania, ale także uwzględnienia sposobu ich przygotowywania, i wpływu specyfiki danej konstrukcji na kształt i formę tego dokumentu. Różnią się one również pod względem zawartości merytorycznej, ze względu na miejsce wykonywania konstrukcji, np. w warsztacie, na linii produkcyjnej, czy montażu prefabrykowanych zespołów na budowie. Przykłady te mogą stanowić wytyczne do przygotowywania podobnych opracowań przez spawalników-technologów dla realizowanych aktualnie zleceń.

Książka jest przeznaczona także dla inżynierów i technologów związanych z produkcją spawalniczą. Może być również wykorzystana przez studentów wydziałów mechanicznych (zwłaszcza specjalności spawalnictwo) i wydziałów budownictwa wyższych uczelni technicznych oraz uczestników kursów Międzynarodowego Inżyniera Spawalnika (IWE), Międzynarodowego Technologa Spawalnika (IWT), Międzynarodowego Mistrza Spawalnika (IWS) i Międzynarodowego Inspektora Spawalniczego (IWI). Książka ta jest pierwszym opracowaniem ujmującym w tak szeroki sposób zagadnienie przygotowywania planów spawania.

Prof. dr hab. inż. Jerzy Nowacki - Zachodniopomorski Uniwersytet Technologiczny w Szczecinie

Dr inż. Lechosław Tuz - AGH Akademia Górniczo-Hutnicza w Krakowie 